\title{
Distance education didactic principles application in teaching
}

\author{
Boris Soldatov ${ }^{1 *}$ and Natalya Soldatova ${ }^{2}$ \\ ${ }^{1}$ Don State Technical University, 344010, Rostov-on-Don, Russia \\ ${ }^{2}$ Russian Customs Academy Rostov Branch, 344002, Rostov-on-Don, Russia
}

\begin{abstract}
The present article analyzes the distance teaching didactic possibilities for foreign language educational process organization. The authors consider the main foreign languages distance teaching components and describe the "Foreign language" academic discipline characteristic features. Moreover, the authors describe the distance learning specifics, taking language disciplines subject features into account, and provide a detailed analysis of the foreign languages distance teaching process components. The importance of various interaction means between a teacher and a student in the foreign language online learning process, including email, Skype, Google Docs, Zoom, Teams and Moodle platforms, is stressed. The Moodle platform application is researched on the example of the language disciplines electronic test control organization at Russian Customs Academy Rostov branch and at Don State Technical University. The interactive methods application in foreign language online teaching is described on the example of classes held in the form of chats, web classes and webinars. The article describes an experiment conducted at Don State Technical University on the project technology application within the "Project Activity Fundamentals" discipline framework in the 1st-year "Linguistics" students' groups. As a result of the project activities, projectspresentations were prepared in English on the topic "My career opportunities in the foreign languages field" and a course module for distance learning in the "Foreign language in the professional sphere" discipline for of nonlanguage faculties students was presented. Basing on the distance teaching components analysis and the ways of their application, the authors arrived at the conclusion that carefully selected didactic tools ensure the organization, students ' activities regulation and their language disciplines educational material content assimilation.
\end{abstract}

\section{Introduction}

Currently, the Russian higher education system is rapidly developing: there are significant changes in the training system organization, involving various educational disciplines teaching process intensification, including foreign languages. One of the innovative means to improve the material studied assimilation and to prepare students for future professional activities is distance teaching. This is training, in which all or most of the training procedures

*Corresponding author:lncs@springer.com 
are carried out using modern information and telecommunications technologies, with the teacher and students being separated [1].

The distance teaching problems are effectively solved with the help of the Internet educational resources allowing you to differentiate the training content and education form choice.

The purpose of the article is to consider the distance learning forms and didactic tools application specifics when teaching English.

The object of the research deals with the foreign language distance learning organization didactic foundations in a single information educational space.

The subject of the study is the English language educational process content with the distance learning application.

\section{Materials and methods}

The foreign language distance teaching components are:

- software component allowing you to manage the learning process, collect, receive and process information about the students' progress in foreign language;

- technical component including a server with special system and application software installed, computer classrooms connected to the server using network equipment, and engineering and technical staff;

- organizational component including the Foreign Languages Department teaching staff;

- methodological component based on the "Foreign language (English)" discipline education and methodological complex applied in the university educational process [2].

The methodological component constitutes the foreign language distance learning basis and deserves the most careful consideration. This component includes practical and test tasks in the electronic form offered to students to study the "Foreign language (English)" discipline, as well as to consolidate and to test the knowledge and skills acquired.

In the foreign languages distance learning process, special attention is paid to the multimedia tools didactic properties and functions being the teaching technical basis, and to the foreign languages educational process conceptual didactic features [3].

Foreign language as an academic subject is characterized by:

- interdisciplinary character, that is, information transmitted in a foreign language is obtained from various fields of knowledge;

- multi-level structure: the student masters speech skills in different speech activity types and expands the language tools knowledge;

- multifunctionality: a foreign language is both a learning goal and knowledge gaining means in various fields.

The foreign languages distance learning specifics, taking into account the subject peculiarities, lies in the students ' specific skills and abilities concerning various speech activity types forming and improving knowledge about various activity methods [4].

Within the distance learning framework, it is important to pay attention to the e-learning materials categories in the "Foreign language (English)" discipline, which can be presented as follows: textbooks and manuals, reference literature, tests, Internet materials.

The methodical material electronic copy should obviously not be shown to the students in the English language distance education process, as it retains the printed source traditional shortcomings, such as static information transmission, lack of response to the students' actions, lack of support, monitoring, etc. It should be transformed it into an interactive electronic textbook or test, which enables the learning process individualization and the modern multimedia tools advantages application, making it more effective than an ordinary 
textbook and even raising foreign language classes efficiency even in case of its being conducted in the traditional (contact) form [5].

Multimedia tools give a foreign language teacher the opportunity to:

1) provide students with specific language material in the modular form;

2) consult students on various course aspects;

3) monitor the students ' proficiency level in the foreign language in various activities: listening, language lexical and grammatical structures, reading and writing.

As a special activity type, speaking can have its original specifics in the interactive (dialogue) mode, when the teacher and the student communicate with each other via the perfect equipment establishing clear connection and interaction. The task of a foreign language teacher is to develop students ' strategies for mastering various speech activity types in the distance learning context, based on the appropriate methodological component [6].

\section{Results}

Interaction between students and teachers can be organized by various means, including: email, Skype, Google Docs, Zoom, Teams and Moodle [7;20].

The advantage of e-mail is that the student performs the task when it is convenient for him, however, the teacher can't "accompany" and "guide" the student in real time.

Skype, Zoom and Teams platforms application allows the English teacher to advise students directly during the practical class.

The Google Docs resource is used when working with documents, presentations, and spreadsheets $[8 ; 19]$.

The Moodle system, which is a virtual learning environment, allows the student to study additional materials in English and complete tasks in special notebooks and on a personal page. Accordingly, teachers have their own access to the system and more extensive opportunities, namely, to create and adjust the English training courses content. It seems appropriate to focus on the foreign languages tests electronic version, since it allows the teacher to regularly monitor the students ' knowledge in each educational material aspect, and students can control their knowledge in each curriculum fragment independently. At the end of the test, the student receives information about the number of correct and incorrect answers, as well as about the test questions with the wrong answers given [9;10].

Tests in the Moodle program are compiled basing on the " Foreign language (English)" discipline working programs content. Multiple choice tests are presented bythe tasks grouped into three sections: "Vocabulary", "Grammar", "Reading Comprehension".

"Vocabulary" section includes the following tasks types: choosing the Russian equivalent for the English word; choosing the English equivalent for the Russian phrase; filling in the blank in the sentence with a suitable word; choosing the words similar or opposite in meaning to the word proposed.

"Grammar" section includes the following tasks: determining the English equivalent for the Russian word proposed basing on the word-building elements underlined; choosing the equivalent for the word form underlined in the sentence; choosing the sentence in Russian corresponding to the English sentence proposed; choosing the sentence in English corresponding to the Russian sentence proposed. According to the "Foreign language (English)" discipline working programs the grammar material covered by the tests includes the following aspects: the English verb tenses in the active and passive voice; modal verbs; adjectives comparison degrees; sequence of tenses and indirect speech. The texts presented in the "Reading Comprehension" section are borrowed from authentic sources and cover various aspects of Russian and foreign customs authorities, companies, and law enforcement 
agencies activities. The reading comprehension tasks section involves choosing the correct answer to the question and the most appropriate title for the text.

Most test assignments are multiple choice tasks requiring students to choose the correct answer from the three variants proposed. Each test begins with a short preamble describing the textbook material sections and grammatical phenomena to be studied before performing the test, as well as the control time estimated [11;18].

The Don State Technical University SKIF educational portal designed on the Moodle basis contains electronic tests in different disciplines, including Foreign Language and Professional Foreign Language (for non-linguistic students), and also in the disciplines envisaged by Linguistics curriculum. For example, the electronic course "Grammar. Nonfinite Verb Forms" contains multiple choice tests on the topics "Infinitive", "Participle", "Gerund". Moreover, the courses offer different tasks for students' independent activities, including the ones with feedback. The SKIF portal materials are widely applied both in contact and distance learning forms.

Since distance learning implies groups joint learning method, English classes are conducted in the following forms: chat classes, web forums, web classes (webinars) $[12 ; 1 ; 13 ; 18]$.

Chat classes implying chat technologies application are conducted synchronously, provided that all the participants have simultaneous access to the chat. These classes are held in the Economics Faculty second year students' groups on the topics "Money and Banks", " Product promotion. Marketing", in the Law Faculty second year students' groups on the topics " Crimes types and concept ", "Customs Crimes", in the Customs Business Faculty first year students' groups on the topics "Passenger inspection. Preflight formalities at the airport", "Personal Effects Customs Declaring" [1; 14].

Web forums are characterized by an asynchronous nature of interaction between students and teachers and present the opportunity to work for a long time period.

Web classes (webinars) have a special advantage in teaching English, as they allow to take into account each student's training level and provide an opportunity to apply an individual approach to learning and to choose the appropriate methodology. Webinars promote the students' involvement in joint communication activities, involving solving certain tasks using the English language knowledge $[15 ; 16 ; 17]$.

The first-year Linguistics students at Don State Technical University have taken part in the experiment concerning project technologies application. The purpose of the experiment was to research students' activities within the new discipline called "Project Activities Fundamentals". The topic of the project developed by the students was "My career opportunities in the field of foreign languages". The first project stage was conducted in the contact form with Internet technologies application. The students working in mini-groups studied Internet sites containing information about job opportunities for specialists in foreign languages skills. The students also interviewed DSTU foreign language teachers, Master courses students and bachelors who have studied and worked in Europe and in the USA via "Work and Travel" and ERASMUS programs. The first project stage result was compiling presentation projects about career opportunities in the foreign language field. The second project stage was conducted online with Zoom platform application. The teacher communicated weekly with each mini-group via Zoom conferences, discussing the main stages of students' further activities. At the end of the second stage, the students credited their project presentations online and presented the methodical materials which were developed when working at the project. As a result of project work, a course module in the discipline "Foreign Language in Professional Sphere" was presented on DSTU SKIF education portal 
developed on the Moodle technology basis. The course module has been designed for nonlinguistic students and contains different tasks for independent activities in online mode.

The results of the research performed are presented in the table below.

Table1. Results of Foreign Language Distance Teaching Application Analysis at Don State Technical University and Russian Customs Academy Rostov Branch

\begin{tabular}{|c|c|c|}
\hline $\begin{array}{c}\text { Foreign Language } \\
\text { Distance Teaching } \\
\text { Application }\end{array}$ & $\begin{array}{l}6 \text { means of communication } \\
\text { between the teacher and } \\
\text { students: }\end{array}$ & $\begin{array}{l}\text { e-mail, Skype, Google Docs, } \\
\text { Zoom, Teams, Moodle }\end{array}$ \\
\hline $\begin{array}{l}\text { Moodle System } \\
\text { Application }\end{array}$ & $\begin{array}{l}\text { Russian Customs Academy } \\
\text { Rostov Branch: } \\
\text { online multiple-choice tests in } \\
3 \text { aspects each containing } 23 \\
\text { tasks }\end{array}$ & $\begin{array}{l}\text { Don State Technical } \\
\text { University: } \\
\text { online multiple-choice tests } \\
\text { containing } 50 \text { tasks each }\end{array}$ \\
\hline $\begin{array}{c}\text { Experiments in Distance } \\
\text { Teaching Technologies } \\
\text { Applications }\end{array}$ & $\begin{array}{l}\text { Russian Customs Academy } \\
\text { Rostov Branch: } \\
\text { online classes at } 3 \text { faculties in } \\
6 \text { topics. }\end{array}$ & $\begin{array}{lr}\text { Don State } & \text { Technical } \\
\text { University: } & \\
\text { Project } & \text { Activities } \\
\text { Fundamentals } & \text { course } \\
\text { application } & \\
\end{array}$ \\
\hline Results of Experiments & $\begin{array}{l}\text { Russian Customs Academy } \\
\text { Rostov Branch: } \\
\text { chat-classes and webinars on } \\
\text { the topics "Money and Banks", } \\
\text { " Product promotion. } \\
\text { Marketing", "Crime types and } \\
\text { concept", "Customs Crimes", } \\
\text { "Passenger inspection. } \\
\text { Preflight formalities at the } \\
\text { airport", "Personal Effects } \\
\text { Customs Declaring" }\end{array}$ & $\begin{array}{l}\text { Don State Technical } \\
\text { University: } \\
67 \text { students-participants of } \\
\text { the project. } \\
10 \text { teachers, bachelor course } \\
\text { students, master course } \\
\text { students interviewed. } \\
13 \text { project-presentations } \\
\text { prepared. } \\
1 \text { course module developed } \\
\text { in the Moodle system. }\end{array}$ \\
\hline
\end{tabular}

\section{Discussion}

Certainly, distance learning in English with the appropriate methodological content has certain advantages compared to the traditional form of education. Learning in remote groups contributes to the knowledge accumulation in the foreign language field, as students constantly exchange information. In addition, distance learning for students is not only an opportunity to deepen their knowledge of the foreign language, but also to acquire the information and communication culture skills.

The indisputable advantage of various English distance learning forms is also the possibility of regular consultations in foreign language with the teacher in the on-line mode and the teacher's individual approach to each student.

\section{Conclusions}

For remote English teaching to be an effective students' professional development system, it is necessary to take into account that this training type, being an important education aspect in general, has its specific forms involving different teacher's and students' joint activity didactic means in terms of electronic information and educational environment application. Foreign language distance learning organizing didactic principles peculiarity lies in the modern information technologies possibility to automate the acquired knowledge control of 
in the field of a foreign language, to monitor the skills forming in reading, speaking, writing and listening.

In addition, adequately selected teaching English didactic means within the distance learning allow students to develop information, communication and reflection skills, since the main part of the material is mastered by students independently.

Thus, the promising didactic tools, methods and teaching technologies development with the focus on distance teaching allows us to increase the foreign languages educational process effectiveness on the individualization and intensification basis, as well as to rethink the teaching English priority as an students' future professional activities integral c

\section{References}

1. B. Soldatov, N. Soldatova, Vektornauki Tolyattinskogo gosudarstvennogo universiteta, Seriya: Pedagogika, psihologiya 2 (37), 42 - 47 (2019).

2. I. Liashenko, Scientific Papers of Berdiansk State Pedagogical University. Series: Pedagogical Sciences 3, 308-315 (2020). doi:10.31494/2412-9208-2020-1-3-308-315

3. N. Bitskinashvili, Journal of Education in Black Sea Region 3 (2), (2018). doi.org/10.31578/jebs.v3i2.136

4. N.L. Adam, F.B. Alzahri, S.CikSoh, N. Abu Bakar, \& N.A Mohamad Kamal, Selfregulated learning and online learning: A systematic review. In $\mathrm{H}$. Badioze Zaman, $\mathrm{P}$. Robinson, A. F. Smeaton, T. K. Shih, S. Velastin, T. Terutoshi, A. Jaafar, \& N. Mohamad Ali (Eds.), Advances in Visual Informatics, Springer International Publishing. 10645, 143-154 (2017)doi.org/10.1007/978-3- 319-70010-6_14

5. T.K.F. Chiu, British Journal of Educational Technology 48 (2), $524-537$ (2017). dx.doi.org/10.1111/bjet.12432.

6. E.R. Pelikan, J. Holzer, S. Korlat, M. Luftenegger, Zeitschrift für Erziehungswissenschaft (2021). doi: 10.1007/s11618-021-01002-X

7. E. Panadero, Frontiers in Psychology 8, 422 (2017). doi.org/10.33

8. A.S. Chow, \&R.A. Croxton, American Journal of Distance Education 31 (1), 20-42 (2017). doi.org/10.1080/089 23647.2017.1262733.

9. Wisdom O. Anyim, International Journal of Asian Education.02(1), 52-63 (2021)doi: 10.46966/ijae.v2i1.83

10. C. Brando-Garrido, J. Montes-Hidalgo, J.T. Limonero, M.J. Gómez-Romero, \&J. Tomás-Sábado, Enfermería Clínica (English Edition) 30 (6), 398-403 (2020). doi.org/10.1016/j.enfcle.2019.07.013

11. F. Erdogan, Eurasian Journal of Educational Research 80, 89-112 (2019). doi.org/10.14689/ejer.2019.80.5

12. M. Angelucci, M. Angrisani, D.M. Bennett, A. Kapteyn, S.G. Schaner, National Bureau of Economic Research. w27749, (2020). doi:10.3386/w27749

13. E.M. Pokrovskaya, L.E. Lychkovskaya, \&V.A. Molodtsova, Foreign language elearning course as an element of city infrastructure for cognitive enhancement for the third age people, In Z. Anikina (Eds.). Integrating engineering education and humanities for global intercultural perspectives, Lecture Notes in Networks and Systems, Switzerland, AG: Springer, Cham, 131, 3-10 (2020). doi.org/10.1007/978-3-03047415-7_1

14. U.D. Ehlers, European Journal of Open, Distance and E-Learning. (2011) doi.org/10.4000/dms.2707. 
15. A.I.V. Vörös and Z. Sárközi, Physics escape room as an educational tool, AIP Conf. Proc 1916, 050002 (2017). http://aip.scitation.org/doi/abs/10.1063/1.5017455

16. T.B. Mikheeva, E.V. Murugova, SHS Web Conf. 70, 07003 (2018)https://www.shsconferences.org/articles/shsconf/pdf/2019/11/shsconf_ictdpp201 8_07003.pdf. doi: https://doi.org/10.1051/shsconf/20197007003

17. N. Osadchaya, O. Kliuchnikova, E. Murugova, IOP Conference Series: Materials Science and Engineering 1079, 042080 (2021). doi: https://iopscience.iop.org/article/10.1088/1757-899X/1079/4/042080

18. T. Mikheeva, E. Murugova, Y. Morozova, V. Demchenko, Training as a major tool of teacher professionalism enhancement, INTED20 20 Proceedings 14th International Technology, Education and Development Conference. 1211-1215 (2020). doi: $10.21125 /$ inted.2020.0417

19. E. Sakharova, N. Revyakina, SHS Web of Conferences (ITNO- 2020). (2020). doi.org/10.1051/e3sconf/20202101804

20. G. Matveeva, L. Novikova, O. Nikoulina, E. Shyrina, O. Gaibaryan, Y. Khoroshevskaya, The role of motivated communicative personality of the student in the conditions of digital economy, ACM International Conference Proceeding Series, Proceedings Papers - 3rd International Scientific and Practical Conference, DEFIN 2020. (2020) https://dl.acm.org/doi/abs/10.1145/3388984.3390621 (2020). 